\title{
AGNIESZKA KIJAK
}

Uniwersytet im. Adama Mickiewicza, Poznań

\section{O nazwach klubów biegowych}

Podejmując się badań nad onimami związanymi z bieganiem, podkreślałam, że ze względu na ogrom materiału muszę ograniczyć się do nazw biegów, z pominięciem nazw klubów biegowych (Kijak, w druku). Teraz wracam do tego tematu, pozwala on bowiem nie tylko na lepsze poznanie języka biegaczy, lecz także samego środowiska sportowców.

Do badań zdecydowałam się wykorzystać bazę danych, jaką są tabele wyników biegów, w których podaje są zwykle: imię i nazwisko zawodnika, czas, jaki osiągnął, miejscowość oraz właśnie klub sportowy. Przedmiotem mojego zainteresowania naukowego uczyniłam dane znajdujące się w ostatniej rubryce, pamiętając, że biegacze mogą dokonać dowolnego wpisu, tzn. podać nazwę rzeczywistego klubu, do którego należą, nazwę grupy, z którą trenują, powód startu w zawodach lub jakikolwiek inny tekst. Analizy dokonałam, uwzględniając zarówno nazwy rzeczywistych klubów, jak $\mathrm{i}$ indywidualne wpisy zawodników.

Do opracowania, podobnie jak w przypadku nazw biegów, wybrałam najnowszy materiał, czyli pochodzący z 2014 roku. Skorzystałam z tabel wyników czterech najbardziej znanych maratonów w Polsce (pod względem historycznym, geograficznym, tradycji i liczby uczestników): Maratonu Poznańskiego, Maratonu Wrocławskiego, Maratonu w Dębnie oraz Orlen Warsaw Marathonu. Analiza danych z tych czterech biegów pozwoliła na uwzględnienie nazw pochodzących z różnych obszarów Polski oraz zwrócenie uwagi na powtarzające się onimy.

Ze względu na zbyt dużą liczbę osób, które dokonując rejestracji uczestnictwa w biegu, uzupełniły również rubrykę „,klub”, nie podejmę się dokładnego opracowania ilościowego różnych typów nazw, lecz wskażę, jakie typy można wśród nich wyróżnić, postaram się ustalić, których z nich jest najwięcej oraz zanalizuję, jaką funkcję (poza zaspokojeniem potrzeby przynależności) pełnią indywidualne wpisy.

Nazwy klubów biegowych jako ideonimy, czyli nazwy własne niektórych wytworów kultury duchowej, zaliczam do chrematonimów ${ }^{1}$. Podobnie uczyniła Kinga Zalejarz

${ }^{1}$ Zgodnie z klasyfikacjami onomastyki polskiej. Por. Jaku s-B ork ow a 1987, E. Breza 1998, Gałkowski 2007. 
w odniesieniu do nazw drużyn piłkarskich, podkreślając, że chrematonimy stanowią bardzo otwartą klasę onimów, obejmującą częściej przedmioty zbiorowe niż indywidualne, a wiele nazw własnych należących do tego działu onomastyki włącza się do niego z powodu braku uzasadnienia przynależności do innego (Zalejarz 2007: 109). Wypada jednak zwrócić uwagę na fakt, że nie wszyscy językoznawcy uznają ideonimy za dział chrematonimii, co zauważył Kazimierz Jaruszewski, analizując nazwy klubów i organizacji sportowych (Jaruszewski 2000). Na początku lat 90. XX wieku Czesław Kosyl do chrematonimii właściwej zaliczał jedynie: nazwy wyrobów kosmetycznych, środków czystości, wyrobów cukierniczych, używek, środków transportu, niektórych rodzajów broni i obiektów wojskowych, sprzętu gospodarstwa domowego, sprzętu audiowizualnego, mebli, dzwonów, nazwy własne rzadkich okazów natury. Ideonimy natomiast klasyfikował jako tzw. chrematonimy niewłaściwe (Kosyl 1993: 439). Ponieważ jednak przedmiotu moich badań nie stanowią nazwy dzieł artystycznych (tytuły filmów, sztuk teatralnych, dzieł muzycznych), które mogą być przedmiotem onomastyki literackiej, lecz nazwy użytkowe, zasadne wydaje się zaliczenie ideonimów, jakimi są nazwy klubów biegowych, do chrematonimów, jednak z uwzględnieniem odrębności podkreślanej również przez Artura Gałkowskiego, który pisze, że tytuły dzieł literackich mogą być rozpatrywane przez teorie literaturoznawcze, nie stanowią więc nazewnictwa ściśle chrematonimicznego. Podobna sytuacja ma miejsce z nazwami filmów, sztuk teatralnych, tytułów dzieł muzycznych itp. (Gałkowski 2011: 41), a zatem również z nazwami klubów biegowych, które jako ideonimy wypada potraktować z uwzględnieniem ich odmienności od innych chrematonimów.

Wśród badanych przeze mnie onimów można wyróżnić nazwy jednowyrazowe: granatowi, Niepokorni, Ejbry, Lameczki, dwuwyrazowe: Wielka Sowa, Night Runners, Drużyna Zenka, Aktywny Relaks, oraz wielowyrazowe: Grodziski Klub Biegacza, Król Julian Team, Lucky Luki Leszno, Dla kochanej Moni. Część z nich zawiera skrótowce, np.: KB Aktywni Środa Wlkp, Klub Biegowy Maniac Poznań, KB Sobótka.

$\mathrm{W}$ tym miejscu warto zwrócić uwagę na ortografię analizowanego słownictwa. Jako nazwy własne powinny być one zapisane wielką literą, jednak nie we wszystkich przypadkach ma to miejsce. Pod względem pisowni nazwy można podzielić na grupy²:

1) nazwy zapisywane w całości wielkimi literami: INTERSPORT TEAM, SUPERSPORT, KOEOBRZEG MORZEM SPORTÓW, RUNPLANET ZIELONA GÓRA;

2) nazwy zapisywane w całości małymi literami: fenix, dady team, mors team;

3) nazwy składające się z dwóch lub więcej wyrazów rozpoczynających się wielką literą: Truchtacz Dobrzyca, Dobczycki Klub Biegacza, Wujek Biega;

4) nazwy składające się z dwóch lub więcej wyrazów zapisanych łącznie, a wyróżnionych przez zastosowanie wielkich liter: NoMoreDesign, NowosolskaGrupaBiegowa, aleTempo, PiatyBeatles;

5) nazwy zawierające kropkę, zwykle będące także adresami stron internetowych, dlatego często rozpoczynają się małą literą, np.: bieganie.pl, obozybiegowe.pl, ekolan-

${ }^{2}$ Podział przeprowadziłam na podstawie wpisów dokonanych przy rejestracji na biegi maratońskie. 
dia24.pl, czasem także wielką, np.: Biegnijmy.pl, Norafsport.pl. Kropki występują też w nazwach zawierających skrótowiec: E.T., K.B. SPRINT Świdwin, A.K.B. Mort;

6) z wykrzyknikiem: Biegiem Radom!, Adrian! Błagam Wolniej!;

7) nazwy zawierające skrótowiec: AKM Olimp Olsztyn, KW Warszawa, CSWL Poznań, NML Przecław.

Jednowyrazowe określenia klubów są najrzadsze. Większość z nich występuje w liczbie mnogiej, np.: Aktywni, Jelonki, Łosice, Mundurowi, ale niektóre również w pojedynczej: Rosomak, Kinomaniak, solo, Ammator.

$\mathrm{O}$ wiele więcej jest zestawień dwu- i wielowyrazowych, często tworzonych z wykorzystaniem transonimizacji. Najliczniej występują połączenia dwóch rzeczowników, z których jeden bywa przeniesioną nazwą własną, np.: Brylant Kórnik, Olimpia Grudziąz, Krokus Kwiatkowice, Harpagan Sosnowiec, Drużyna Zenka, Klub Maratończyka VLO Poznań, Pędziwiatr Białystok, Brylant Kórnik, Maratończyk Poznań, lub oba są wyrazami pospolitymi, np. Panowie Koledzy. Pojawiają się też zestawienia przymiotnika z rzeczownikiem, np.: Babimojski Klub Biegowy, wolny biegacz, Osiedlowe Kojoty, Poranny Biegacz, Siedmiomilowe Buty, Wielka Sowa, lub imiesłowem przymiotnikowym czynnym, np.: Biegające Łokcie, Klub Biegających Leśników, Lew Goniacy Zajaczka, Kaźmierski Klub Morsujacego Biegacza. Mamy również do czynienia z relacją rzeczownika z czasownikiem, np.: Wilda Biega, Karol się katurla, GIRA SIE KRECCI, Maciek biega. Rzadkie są natomiast połączenia rzeczownika z liczebnikiem, np.: Świnki Trzy, oraz czasownika z rzeczownikiem, np. Miałem szczesście.

Ponieważ analizowany przeze mnie materiał zawiera indywidualne wpisy biegaczy dotyczące ich przynależności klubowej, obejmuje on zarówno nazwy oficjalne klubów, np.: AZS AWF Katowice, KS Zryw Radziejów, Grodziski Klub Biegacza, Wolsztyński Klub Biegowy, jak i nieoficjalne, takie jak: Białostocka Sekta Biegaczy, Truchtacz Mysłowice, Kapitan Bomba Team, Wujek Biega.

Onimy oficjalne zawierają zwykle nazwę miejscowości. Część toponimów przywołana została w formie derywowanych od nich przymiotników, np.: Grodziski Klub Biegacza, Wolsztyński Klub Biegowy, Strzeliński Klub Biegacza, Kamiennogórska Grupa Biegowa, Nowosolska Grupa Biegowa. Jako składnik nazw klubów biegowych toponimy pojawiają się jednak również w formie podstawowej, nieodmiennej, np.: Olimpia Grudziądz, Klub Biegowy Maniac Poznań, Klub Biegowy Sobótka, Brylant Kórnik, Pędziwiatr Biatystok.

Większość oficjalnych nazw realnie istniejących klubów zawiera skrótowce: $K B$, $K S$, oznaczające:

KB - Klub Biegowy, Klub Biegacza, np.: KB Szamotuły, KB Sobótka, KB Maniac Poznań, KB Lew Legnica;

KS - Klub Sportowy, np.: KS Zryw Radziejów, KS Ice Mat Team Ostrów Wielkopolski, KS Polonia Środa Wlkp.

Często stosowanym akronimem jest też BBL, czyli Biegam Bo Lubię - człon występujący w wielu nazwach wraz z toponimem, związany z akcją Biegam Bo Lubię, zapoczątkowaną przed dziennikarzy Programu III Polskiego Radia, mającą na celu pro- 
mowanie aktywności fizycznej (www.biegambolubie.com.pl), np.: Biegam Bo Lubię Białystok, Biegam Bo Lubię Opole, Biegam Bo Lubię Lidzbark Warmiński, Biegam Bo Lubię Warszawa.

Chrematonimy nieoficjalne są dużo bardziej różnorodne. Wyróżniają się wśród nich nazwy odnoszące się do założyciela klubu, czyli chrematonimy deantroponimiczne, zawierające imiona lub nazwiska biegaczy, np.: Drużyna Zenka, Zuzia i Olek, Team Kopeć, Rodzina Gezela, Antoniewicz Maraton Team. Na podstawie analizy i poszukiwań w innych źródłach (portalach i forach biegowych) można stwierdzić, że są to kluby rodzinne, towarzyskie czy wręcz okolicznościowe - powstałe przy okazji udziału kilku osób z rodziny lub znajomych w danym maratonie. Imiona występują tutaj w formie zdrobnień lub spieszczeń, np.: RENIATEAM, Drużna Zenka, ZUZIA I OLEK, $Z U Z Y M I S$. W nazwach wykorzystano jednak nie tylko zdrobnienia imion, lecz także nazw pospolitych, np.: MISIEK, KM Truchcik Łubianka. Przywołane zdrobnienia pełnią najprawdopodobniej funkcję informowania o pozytywnym stosunku do danej osoby lub obiektu.

Nomina propria przeniesione $\mathrm{z}$ nazwisk występują w formie nieodmiennej, np.: Team Kopeć, Rodzina Gezela, Antoniewicz Maraton Team ${ }^{3}$. Leksem team, oznaczający po angielsku drużynę, pojawia się zresztą nie tylko w onimach zawierających $\mathrm{w}$ formie afleksyjnej nazwiska, lecz także nazwy miejscowości, np.: Team Pleszew, Nowa Huta Team, czy firm, np. Team Cukiernia Nova, a także wyrazy pospolite: mors team, Ciuchcia team, SAMODYSCYPLINA TEAM.

Zapożyczenie to pojawia się zatem w różnych onimach, w większości nieoficjalnych. W nazwach klubów biegowych zawierających określenia firm oprócz leksemu team występuje często też cząstka run w wyrazach runners (Volkswagen Group Runners Team, BPH Runners Team) lub running (T-Mobile Running Team, Opel Running Team, Eaton Running Team, Łódź Running Team), co ma dodatkowo uwydatniać, że jest to drużyna biegowa. Wyraz team, podobnie jak jego polski odpowiednik drużyna, podkreśla przynależność do grupy. Słowo drużyna w nazwach występuje znacznie rzadziej, np.: Odolanowska Drużyna Biegowa, Drużyna Zenka. Jednostkowe są przykłady zastąpienia tych wyrazów leksemem brygada, np.: Pędząca Brygada Juliana. W nazwach oficjalnych podobną funkcję pełnią człony: klub biegowy, klub biegacza, które jednak bardziej podkreślają sportowy charakter klubu aniżeli odzwierciedlają przynależność do grupy.

$\mathrm{W}$ analizowanym materiale można znaleźć jeszcze inne nazwy, również z leksemem run, np.: Run Bydgoszcz, niektóre z nich całkowicie w postaci obcojęzycznej, np.: 4 Run Team, Run Vegan, Run and Gun. Kilka razy w wersji angielskiej zapisane zostało też słowo maraton, np.: Marathon Team Konin, Wojtowicz Team Marathon. Inne angielskie nazwy pojawiają się jedynie w przypadku nazw drużyn zawodników z zagranicy.

Wśród nazw klubów biegowych można wyróżnić także tzw. chrematonimy frazematyczne, czyli onimy przekazujące informację (dokładniejszą niż propria dotąd ana-

\footnotetext{
${ }^{3}$ Za niejasne etymologicznie, choć możliwe, że reprezentujące ten sam typ, uznać trzeba Gruby Team i Team Wiewióra.
} 
lizowane) o nazwanym obiekcie. $\mathrm{Z}$ formalnego punktu widzenia są one wieloskładnikowe i precyzyjnie opisują określony obiekt. Większość chrematonimów frazematycznych jest swoistym komunikatem mikrotekstowym (Gałkowski 2011: 274-276). Przykładami mogą być nazwy wskazujące na cel powstania klubu, powód samego biegania lub charakteryzujące grupę, np.: Zabiegani Po Uszy, Biegajacy Tczew, Klub Biegowy Spoceni Nowa Sól, Chcialem Se Pobiegać, Fajna Grupa Biegowa. Tego rodzaju chrematonimy są typowe jako nazwy indywidualnych biegaczy, którzy rubrykę „klub” wykorzystali do przekazania informacji na swój temat. Można to zaobserwować w chrematonimach: Biegam Bo Krzyczy, Amator, Samotny Wojownik, Wolny Biegacz, Wolny Strzelec.

Wiele nazw klubów biegowych, zwłaszcza tych stworzonych na potrzeby startu w maratonie, powstało w wyniku zabaw językiem i tworzenia tzw. konstrukcji retoryczno-dyskursywnych. Za takie można uznać onimy zawierające różnego rodzaju hasła i sentencje, np.: Biegam, więc jestem. W nazwie tej widać wyraźne nawiązanie do najbardziej znanej myśli Kartezjusza „Myślę, więc jestem” oraz wcześniejszej Augustyna z Hippony: „Wątpię, więc jestem”. W innych tego typu propriach wyrażone są uczucia, np.: Kocham Kasię, wyznania dotyczące startu: Nie wiedziatem, że pobiegnę, a także hasła motywujące: Zawsze do mety, Nigdy się nie poddawaj. Konstrukcje takie powstały również z uwzględnieniem elementów stylizowanych na obcojęzyczne, np. w nazwach: Los Bieganeros, wieRUNszów (klub z Wieruszowa). Wykorzystują również elementy terytorialnych (nieogólnopolskich) odmian języka. $Z$ gwary poznańskiej czerpią przykładowo chrematonimy: Gira się kręci, Ejbry, Karol się katurla (Gruchmanowa, Walczak (red.) 1999) 4 .

Słownictwo potoczne wykorzystane zostało również w nazwach zbiorowych o charakterze deskryptywnym: Fajna Grupa Biegowa, Kibole w biegu $u^{5}$ oraz w indywidualnych, stworzonych prawdopodobnie z potrzeby ekspresji, np.: Chciałem se pobiegać, Tak se pomykam.

Tworzenie oryginalnych nazw ma zapewne na celu zarówno wyróżnić klub, jak i zaintrygować inne osoby rejestrujące się do udziału w zawodach czy też tylko śledzące wpisy. Prawdopodobnie dlatego zawodnicy wykazują się ogromną kreatywnością. Często mamy również do czynienia z intertekstualnością. W przypadku nazw klubów biegowych konieczne jest bowiem wyróżnienie jeszcze jednej istotnej grupy chrematonimów, o której także pisał Gałkowski. Są to chrematonimy odtytułowe, czyli nazwy, które są cytatami tytułów dobrze znanych utworów literackich, legend, baśni, bajek, filmów, fragmentów wierszy i piosenek, powiedzeń sławnych ludzi (Gałkowski 2011: 283). Przykładami takich chrematonimów są nazwy klubów zawierające tytuły filmów, np. Zielona Mila Team, lub bajek, np. Siedmiomilowe Buty. Kilka analizowanych prze-

${ }^{4}$ Znaczenia wykorzystanych tu poznańskich leksemów to: gira 'noga', ejber 'mężczyzna silnej postury, nieokrzesany, pełen temperamentu; też o chuliganie', katurlać się 'toczyć się' (Gr u c h m a n o w a, Walczak (red.) 1999).

${ }^{5}$ Słowa kibol, fajny uznane za potoczne zgodnie ze „Słownikiem polszczyzny potocznej”, zob. Anusiewicz, Skawiński 2000. 
ze mnie onimów prawdopodobnie wiąże się z tekstami piosenek, np.: Co JA robię tu??? ${ }^{6}$, TEAM, coco jumbo $i$ do przodu ${ }^{7}$. W innych przypadkach mamy do czynienia $\mathrm{z}$ transonimizacją nazw bohaterów bajek, np.: Kubuś Puchatek, Król Julian Team, BRYGADA RUMCAJSA ROJBERA.

Kilka nazw nawiązuje do bajek o zwierzętach, np. Struś \& Kojot ${ }^{8}$, Świnki Trzy. Pojawiają się też propria zawierające pospolite określenia zwierząt - a więc bazujące na leksyce ogólnej — np. nazwy ptaków: Klub Orła Bielika, Orlęta Łuków, Puszczyk Bukowy, Wielka Sowa. Propria z wyrazem orzeł mogą odwoływać się do tradycji narodowej - dawniej wiele organizacji i stowarzyszeń sportowych rejestrowano jako Orzet czy Sokót (Jaruszewski 2000: 225). Wśród analizowanych przeze mnie onimów występuje również nazwa drużyny: Jarosławska Grupa Biegowa SOKÓL. Wykorzystanie nazw pospolitych ptaków w onimach dotyczących klubów biegowych może też wiązać się z używanym często przez biegaczy czasownikiem lecieć jako synonimem biegać: „Lecieliśmy chodnikami wzdłuż głównej arterii Trójmiasta” (biegaczzpolnocy.blogspot.com). W związku z lataniem zasadne wydaje się również utworzenie deantroponimicznych nazw z imieniem boga Hermesa, odznaczającego się atrybutami, takimi jak: petasos — podróżny kapelusz ze skrzydłami oraz skrzydlate sandały, dzięki którym przemieszczał się z miejsca na miejsce. Jego imię pojawia się w nazwach klubów: $K B$ Hermes Gryfino, HERMES Świdnica.

Onimy klubów biegowych zawierają także nazwy innych zwierząt, np. drapieżników lądowych: Klub Biegacza Lew Legnica, K.B. Gepard, TIGER TEAM. Tygrys i gepard kojarzą się z szybkim bieganiem, a wszystkie trzy z polowaniem i walecznością koniecznymi w rywalizacji, jaką jest bieg maratoński.

Ciekawy przypadek stanowi zestawienie Cwatujace Wieprze, gdyż wieprz jest zwierzęciem, które kojarzy się z czynnościami innymi niż bieganie. Cwałowanie jest natomiast zarezerwowane dla innych zwierząt, a mianowicie — koni. Jak podaje „Nowy słownik języka polskiego”, cwałować w znaczeniu ‘biec bardzo szybko’ mogą też ludzie $^{9}$. Być może nieprzypadkowa jest wielka litera w słowie Wieprz, ponieważ można ‘cwałować po Wieprzu' (,woda na bystrzu tworzy fale, pieni się, cwałuje”), czyli płynąć kajakiem po rzece Wieprz (kajakiempowieprzu.pl).

Autorzy nazw klubów dokonali również modyfikacji związków frazeologicznych, np.: w onimie: Zabiegani po uszy. Według słowników frazeologicznych (SFJP, SFWP) można jedynie angażować się w coś po uszy, być, siedzieć w czymś po uszy, zadurzyć, zakochać się po uszy, czerwienić się, rumienić się po uszy; można też mieć czego lub kogo po uszy. Słowniki nie podają żadnego związku połączenia wyrazu bieg ze słowem uszy.

Ciekawa jest też nazwa: We mgle po tydki. Obecne w onimie wyrażenie we mgle prawdopodobnie odnosi się do związku frazeologicznego tonać we mgle. Po tydki mogłoby wskazywać na to, że mgły jest niewiele, sięga bowiem tylko po łydki. W tym wy-

\footnotetext{
${ }^{6}$ Fragment piosenki Elektrycznych Gitar.

${ }^{7}$ "Coco Jumbo" to tytuł piosenki zespołu Mr. President.

${ }^{8} \mathrm{~W}$ polskim thumaczeniu bohaterowie mają imiona Wiluś Kojot i Struś Pędziwiatr.

${ }^{9}$ Cwałuje się również w tańcu ludowym i towarzyskim.
} 
padku należałoby jednak kojarzyć owe łydki z biegaczami, dla których łydki są jedną z najważniejszych, bo mocno wykorzystywanych podczas biegu, części ciała.

Związek frazeologiczny upadać (przed kimś) na twarz został zastąpiony paść na ryj w nazwie Padt na ryj Team, którego nie notuje żaden słownik. W SFWP możemy znaleźć jedynie na krzywy ryj w zupełnie innym znaczeniu. Upadać na twarz oznacza 'korzyć się, oddawać komuś cześć'. Autor nazwy Padt na ryj Team miał raczej na myśli upadek jako skutek zmęczenia i wysiłku związanego z biegiem, nie zaś wyrażenie poddaństwa czy szacunku. Temu znaczeniu najbliższy jest związek frazeologiczny $p a-$ dać na twarz, pot. na nos, na pysk, na mordę notowany w „Wielkim słowniku frazeologicznym PWN z przysłowiami” w znaczeniu 'być bardzo zmęczonym'.

Wieloznaczność słowa ochota, będącego zarówno słowem oznaczającym 'pragnienie czegoś lub doświadczenia czegoś' (NSJP), jak i nazwą dzielnicy Warszawy, wykorzystali twórcy nazwy: Biegamy z Ochota.

Kilka nazw klubów biegowych zawiera cyfry podkreślające dystans, który zawodnicy mają do pokonania, np.: 42.195 Wejherowo, 42doszczęścia.pl, NETTO GRUPA BIEGOWA 42195 DĘBNO lub czas, w którym zamierzają to zrobić, np.: 3:33 Team. Cyfry pojawiają się też w zastępstwie angielskiego leksemu for, np.: 4 Run Team. Dystans, do którego biegacze się przygotowują, obrazują również nazwy niezawierające cyfr, np.: Maraton Leszno, Marathon Team Konin, Maratończyk Poznań, Klub Maratoński Truchcik Łubianka. Prawdopodobnie ze względu na to, że uwzględniłam jedynie tabele wyników maratonów, nie występują nazwy zawierające określenia dystansu innego niż maraton.

Chrematonim to stały element reklamy (Gałkowski 2011: 340), dlatego onimy firmowe wykorzystywane w reklamach, czyli marketingowe, zostały również użyte do tworzenia nazw klubów ${ }^{10}$. Biegacze w rubryce: „klub” wpisali m.in.: Lux Med, PZU Sportteam, VW Poznań, Siemens, Orange Polska, Miłostaw Fortuna, Renault.

Wpisane przy rejestracji onimy są też nazwami instytucji i organizacji: Marynarka Wojenna, Straż Miejska Poznań, Muzeum Narodowe w Poznaniu, Teatr Wielki, Poczta Polska. Informują one, że członkowie czy pracownicy tych instytucji również biegają, jednocześnie podkreślając związek biegaczy z daną grupą. Często instytucje opłacają start w zawodach swoim pracownikom, promując w ten sposób aktywny tryb życia, ale także własną organizację. Zawodnicy reklamowali też swoje blogi i strony internetowe, jako nazwę klubu podając: Poranny Biegacz dawnrunnin.blogspot.com, BIEGAM z SERCEM.pl, biegampolodzi.pl,www.biegajacamatka.pl, ponadsiebie.pl.

Analizowane nazwy klubów biegowych pełnią też funkcje informowania o charytatywnych i społecznych akcjach, np.: Razem dla Piotra, Drużyna Szpiku, Biegaj-Zapobiegaj, Biegnę, żeby Bartek mógt biegać. Niektóre z nich poprzez przywołanie świętych wyrażają idee i poglądy religijne. Częste są nazwy z imieniem Jezus, np.: Drużyna Jezusa, Jezus is my Leader, Biegnę dla Jezusa. Autorzy nazw klubowych przywołują też innych świętych wpisując w rubrykę „klub”: Św. Antoni, Św. Michat.

\footnotetext{
${ }^{10}$ Jest to zabieg często wykorzystywany w nazwach klubów sportowych — por. uwagi na temat tworzenia nazw klubów sportowych w artykule Bogusława Dunaja (D u n aj 2008: 489-494).
} 
Na podstawie opracowanego przeze mnie materiału można stwierdzić, że nazwy klubów biegowych mogą pełnić różne funkcje, głównie jednak informacyjną, przekazując wiedzę o grupie biegowej, celu biegania, akcji charytatywnej czy też idei. Chrematonimy te ukazują przede wszystkim charakter klubu, czyli fakt, że jest to klub biegowy. Służą temu leksemy: klub (Klub Biegowy Biała Biega), biegać (Pogoria Biega), biegowy (Klub Biegowy im. Piotra Sękowskiego w Płońsku), biegacz (Miński Klub Biegacza), zabiegany (Zabiegani Lusówko), aktywny (Klub Biegowy Aktywni Środa Wlkp.). Chrematonimy odnoszące się do pojedynczych biegaczy pokazują, że część z nich czuje się związana z jakąś grupą, zwykle lokalną, podaje zatem nazwę fikcyjnego klubu zawierającą toponim. Inni wprost podkreślają indywidualizm treningów poprzez wpisy: Bez Klubu, Żadna, Samotnik, Samotny Wojownik, Wolny Strzelec. Zebrany i opracowany przeze mnie materiał pozwolił zatem pokazać różnicę pomiędzy nazwami a charakterem oficjalnym lub nieoficjalnym grup biegowych.

\section{Bibliografia}

Słowniki i encyklopedie

Anusiewicz J., Skawiński J., 2000, Słownik polszczyzny potocznej, Warszawa-Wrocław 2000. SFWP: Słownik frazeologiczny współczesnej polszczyzny, red. S. Bąba, J. Liberek, Warszawa 2001.

NSJP: Nowy słownik języka polskiego, red. B. Dunaj, Warszawa 2005.

Gruchmanowa M., Walczak B. (red.), 1999, Słownik gwary miejskiej Poznania, wyd. II z suplementem, Warszawa-Poznań.

Rzetelska-Feles zko E. (red.), 1998, Polskie nazwy własne. Encyklopedia, Warszawa-Kraków.

SFJP: S. Skorupka, Słownik frazeologiczny języka polskiego, t. I-II, Warszawa 1968.

Słownik języka polskiego PWN (dostęp online: www.sjp.pl).

Wielki słownik frazeologiczny PWN z przysłowiami, oprac. A. Kłosińska, E. Sobol, A. Stankiewicz, Warszawa 2005.

Artykuły i monografie

B r e za E., 1998, Nazwy obiektów i instytucji związanych z nowoczesną cywilizacją (chrematonimy), [w:] Rzetelska-Feleszko (red.) 1998, s. 343-361.

Du naj B., 2007, Teoretyczne problemy onomastyki sportowej. Sposoby identyfikacji klubów, [w:] Nowe nazwy własne. Nowe tendencje badawcze, red. A. Cieślikowa, B. Czopek-Kopciuch, K. Skowronek, Kraków, s. 489-494.

Gałk ow ski A., 2007, Socjoideonimy a chrematonimy — miejsce nazw organizacji i inicjatyw społecznych w dynamice onimicznej języka, [w:] Nowe nazwy własne. Nowe tendencje badawcze, red. A. Cieślikowa, B. Czopek-Kopciuch, K. Skowronek, s. 495-508.

— 2011, Chrematonimy w funkcji kulturowo-użytkowej. Onomastyczne studium porównawcze na materiale polskim, włoskim, francuskim, Łódź.

Jaku s-B ork ow a E., 1987, Nazewnictwo polskie, Opole.

J aru szew ski K., 2000, Nazewnictwo polskich klubów i organizacji sportowych, [w:] Onomastyka polska a nowe kierunki językoznawcze, red. M. Czachorowska, Ł.M. Szewczyk, Bydgoszcz. 
Kij a k A., w druku, Dlaczego bieg powinien mieć nazwę i co ona o nim mówi? (na podstawie nazw zawodów biegowych rozegranych w Wielkopolsce w 2014 roku), [w:] M. Gaze, P. Góralczyk-Mowczan, Bogactwo językowe i kulturowe Europy w oczach Polaków i cudzoziemców 3.

K o s yl C., 1993, Chrematonimy, [w:] Współczesny język polski, t. 2, red. J. Bartmiński, Wrocław.

Li c a Z., 2005, Nazwy pomorskich klubów piłki nożnej, [w:] Nazwy pogranicza, red. J. Ignatowicz-Skowrońska, Szczecin, s. 379-387.

Wilc zy ński W., 1999, O nazwach polskich klubów piłkarskich występujących w ekstraklasie w latach 1927-1998, Prace Językoznawcze I, Olsztyn, s. 116-127.

Z a le j ar z K., 2007, Nazwy drużyn piłkarskich w grze internetowej Hattrick, Poznańskie Studia Polonistyczne 14 , s. 105-116.

\section{SUMMARY}

\section{On running team names}

Keyw ord s: onomastics, ideonims, chrematonyms, running team names, marathon.

Słow a kluczowe: onomastyka, ideonimy, chrematonimy, nazwy klubów biegowych, maraton.

The subject of the article is an attempt to describe the running team names: the structure and the meaning. This category of onyms is new and connected with popularity of running. A basis is the material collected during the marathons in 2014. 